\title{
THE MIGRATION AND IDENTITY RECONSTRUCTION OF TEMPORARY UKRAINIAN LABOUR MIGRANTS IN POLAND
}

\section{Introduction}

Migration is an integrative part of the world history. There exist numerous examples of the shift of people - voluntarily or by force, individuals and groups as well as whole nations, labour migrants and refugees. The late $20^{\text {th- }}$ and the early $21^{\text {st }}$ century have been characterized both by a significant increase in the international movement of the population and the intensification of migrations within countries. This happened due to different reasons and events all over the world. The first two of them are the mutually dependent, interrelated processes of globalization, on the one hand, and localization, on the other. Globalization leads to a weakening of many world "boundaries" and encourages cultural homogenization, economic integration as well as the "increasing consumption of global cultural merchandise (from soap operas to Coca-Cola) and an increased flow of people to and from various destinations." (Eriksen, 1993: 149) At the same time one can speak about "new localisms - usually of an ethnic, religious or regional nature - continue to emerge and to assert their demands vis-ŕ-vis the centres." (Eriksen, 1993: 150) From where I stand, the "new localism" with its inherent struggle for cultural or political autonomy and its emphasis of religious tradition and cultural uniqueness translates into an identity search in the quickly changeable world, too. In other words, this identity search equals to a non-stop struggle

* mgr Mykoła Jaworski, Katedra Politologii i Stosunków Międzynarodowych Narodowego Uniwersytetu „Lwowska Polytehnika” (Ukraina, Lwów), e-mail: mykola.iavorskyi@gmail.com. 
between the "Lexus" and the "Olive tree." (Friedman 2002) Another reason for the migration increase is the world political and economic conditions going on at the turn of the $20^{\text {th }}-21^{\text {st }}$ century such as, e.g. the collapse of USSR and the creation of new countries within the post-communist space; the military conflicts in the Balkans and in the Middle East; the unstable economic and political situation in the countries of South America; the civil war at Syria, and so on. These social processes and conflicts have generated numerous migration flows by permanent immigrants, temporary migrants, refugees and repatriates.

The intensification of migration has led to changes in migrants' identities, both on individual and group level. In the first case such changes are more dynamic, while they take longer in the second instance. In spite of it elusive and changeable features, the concept of identity has developed very intensively in the recent years. The last two decades have been marked by the powerful outburst of interest in the problem of identity, the assertion of postmodernism, globalisations, the appearance of numerous social movements, and an increase in migration. The transformations and crises also are accompanied by the important changes in the structure of personal identities and values. As for the post-communist societies, the disintegration of the USSR and the collapse of the ruling communist ideology, the gaining of political independence and the wave of national revival, economic crisis and geopolitical indefinite - all these changes lead average citizens, among others, to experience identity problems. As a consequence, many post-Soviet people ask the questions: Who are we? And where are we going? The aim of this paper is therefore to research the migration context and the reconstruction specifics of the linguistic, religion, professional, family, national and religion identities of female Ukrainian labour migrants in Poland.

\section{Migration and identity: definitions, typology and approaches}

On the whole, migration is a mobility of population from one defined area to another. (Richmond 1988: 88) S. Castels and M.J. Miller have distinguished the following tendencies in the world migration movement which "are likely to play

\footnotetext{
1 "Lexus" is a Japanese supersonic car that embodies globalization, whereas the "Olive tree" is one which embodies traditions and separate nations, and hence the "localism" of T.H. Eriksen as in the book of T. Friedman, The Lexus and the Olive Tree (Фрідмен, Томас Лорен. “Лексус і Оливкове дерево. Зрозуміти глобалізацію.” Пер. з англ. Мар'яни Прокопович та Роман Скакуна. Незалежний Культурологічний Журнал “ї” 2002: 622).
} 
a major role in the next 20 years:" globalization, acceleration, differentiation, and feminization of migration. (Castels, Miller 1993: 8)

Temporary labour migration constitutes an important form of each state's international relations and economic politics. Such migration means voluntary space mobility from one's native country to another in order to improve a person's economic situation. One characteristic of temporary labour migration is that, in the majority of cases, the migrant comes back to his/her sending country. There are different types of labour migration regarding the time framework but usually the entire process gets divided into long- and short-term (circular) migration. According to some researches, the time criterion distinguishing the short-term migration from the long-term one is one year. (Korczyńska 2003: 16) The International Labour Organization defines labour migrants as "persons who are economically active in a country of which they are not nationals and excluding asylum-seekers and refugees." (Conditions, 1996)

When analysing migrants' identity reconstruction trajectory I have used the four-stage model of migratory movement offered by S. Castels and M.J. Miller. This model comprises the following:

"Stage 1: temporary labor migration of workers, remittance of earnings and continued orientation to the homeland;

Stage 2: prolonging of stay and the development of social networks based on kinship or common area of origin and the need for mutual help in the new social environment;

Stage 3: family reunion, growing consciousness of long term settlement, increasing orientations towards the receiving country and emergence of ethnic communities with their own institutions (associations, shops, cafes, professions);

Stage 4: permanent settlement which depending on the policies of the government and the behaviour of the population of the receiving country, leads either to secure legal status and eventually citizenship, or to political exclusion, socio-economic marginalisation and the formation of permanent ethnic minorities." (Castels, Miller 1993: 25)

The contemporary perception and understanding of identity is more open than it used to be 50 years ago. Researches have moved from the understanding of identity as inner, private and stable to its perception as a changeable, open to negotiation and unstable phenomenon. The creation of personal identity begins with identification and "involves both social structural and symbolic components." 
(Mach 1993: IX) Identity formation is a process of the individual identification with social behvioural patterns. Usually there is a distinction between personal (individual) and group (collective) identities. The Polish researcher Z. Mach points out that an individual's identity has been re/created and changed through "the memory of the past, fears for the future and elements of the present environment, through the integration, adaptation and conflict." (Mach 1993: 4)

One can speak about identity only in relation to others. Thus, we can find ourselves only in relation with other persons and understanding the "other" as a more common concept including, first of all, the relation between "we" and "them." As T.H. Eriksen argued, "people classify others not only along the axis of identity versus differences (the basic Us-Them mechanism), but also according to perceived degrees of differences." (Eriksen 1993: 66)

Also, "identities are ambiguous and this ambiguity is connected with negotiable history and a negotiable cultural context." (Eriksen 1993:73) As a rule, the dominant group have seen migrant culture as static and regressive. Still, a reference to the culture of origin helps migrants find a way of organizing resistance to exclusion and discrimination. "A static, primordial culture cannot fulfill this task, for it does not provide orientation or protection in a hostile environment. The dynamic nature of culture lies in the capacity to link a group's history and traditions with the actual situation in the migratory process." (Castels, Miller 1993: 33-34) The above quotes are one more proof that identity is a dynamic, contextual phenomenon, especially in the situation of migration.

The term "to reconstruct" is considered as "construct again" or "create or act out (a past event) from evidence." (Oxford 2002: 697) Z. Mach argues that, for a more or less successful identity reconstruction, "the most important question is whether a migration is voluntary or forced." (Mach 1993: 177) The voluntary migration guarantees a ready-to-reconstruct life in a new land and is thus contrary to the forced migration where "people are not prepared to move and ready for regarding their lives in a new place." (Mach 1993: 178) The most successful migrations are those when migrants want to assimilate in the host society in spite of the reasons for their mobility; yet, on the whole, migrants' "passiveness and indifference make creation of new identity impossible." (Mach 1993: 178) Z. Mach distinguishes the following conditions necessary for a successful identity reconstruction among migrants: the voluntary decision for immigration and voluntary migration; the "dissatisfaction with former conditions of life and lack of emotional attachment to the former land:" whether "the new territory is already inhabited by a community," "the feeling that the new land is the legal property 
of the settlers and the arrangement is stable and permanent," and the "similarity between the new and old land." (Mach 1993: 178-182) The similarity between the new and the old land includes both natural and cultural dimension and can make integration of migrants easier or harder.

\section{Labour migration on the post-Soviet space. The case study of Ukraine}

The collapse of the symbol of the Cold War - the Berlin Wall was only the first step in regard to the disintegration of the USSR. In the period of 1990-1991, after the disintegration of the Communist Block and of the USSR, fifteen independent states were created on the ex-territory of the Soviet Union. These transformations were accompanied, on the one hand, by the national revival, great hope and belief in a better life, and, on the other hand, by the economic chaos, massive unemployment, political strife and instability. Permanent and temporary migration has been considered a way of deciding the economic problems. Hence, after the 1990s, many an East European country has become a "donor" of labour migrants, permanent immigrants and, to a lesser degree, refugees.

The contemporary international migration is often explained in terms of the "North-South gap." "The North-South gap is the differentials in life expectancy, demography, economic structure, social conditions and political stability between the industrial democracies and most of the rest of the world - looms as a major barrier to the creation of a peaceful and prosperous global society." (Castels, Miller 1993: 124) I would add here that there is also a reason to speak about the "West European - East European gap" in the European context, especially in the context of the late 1990s.

Ukraine is a one of the main "donor" countries in Eastern Europe. Since the early 1990s hundreds of thousands of Ukrainians have found work in Poland, the Czech Republic, Greece, Italy, Spain, Portugal and so on. The emigration increase happened mostly due to two main reasons: the falling of the "iron curtain" and the failure of economic reforms in the newly independent Ukraine. As a consequence of the latter, the bigger part of the Ukrainian population had stayed below the poverty line. Thus, temporary labour migration has been considered both a way to improve economic well-being and an alternative to permanent immigration. The exact numbers of Ukrainian citizens working abroad are not known. According to some sources, these comprise 1,5 to 7 million people. (Зовнішня 2009) Many Ukrainian natives went abroad as tourists or guests, and resolved to stay there and work illegally. According to the survey data of the Institute of Sociology of 
National Academy Scientific of Ukraine, the highest readiness to migrate occurs among the western Ukraine population (43.5\%). The populations of the Lviv region (10.5\%), the Ivano-Frankivck region (10.5\%), and the Ternopil' region (9.7\%) are going to work abroad most often (Паніна 2005). A lot of labour migrants are originally from small towns (33\%) and villages (28\%) (Прибиткова 2002: 159). Poland is one of the popular destinations among labour migrants from western Ukraine. Ukraine's neighbor, Poland was a visa-free country up to 2003 and the average living standards and wages there are higher comparatively to Ukraine. According to some sources, more women (75\%) then men went to work in Poland. (Давимука 2001: 322)

\section{Identity change and reconstruction among Ukrainian female migrants with the Polish work experience}

Twelve semi-structured interviews with temporary female labour migrants ${ }^{2}$ are used for analyzing the changes and reconstruction of personal identities. All the interviewed women come from the western Ukraine (Ternopil', L'viv and Ivano-Frankivs'k regions). The majority of them were born between the 1950s and 1960s. Eight out of twelve respondents have a higher education. Nine women have an experience of family life and children. Five of them are married, four of them are divorced and three - single. Two women have been staying in Poland from 1997-1998, with breaks, while others - from 2000-2002, with breaks as well.

The first and partly the second stage of the above mentioned model by S. Castels and M.J. Miller correspond to the respondents' migration experience. They are temporary labour migrants who send their monthly remittance back home and continue to be Ukraine-oriented. Some of these women, however, have already prolonged their stay abroad and developed social networks. A few respondents have joined the non-government, migration-oriented organizations created by the Ukrainian or the Ukrainian and the Polish alike in Poland. Theirs is therefore a voluntary migration for economic reasons because the interviewed women are dissatisfied with the economic conditions of life in Ukraine.

There are both natural and cultural similarities between the "new" (Poland) and "old" (Ukraine) lands. The geographical proximity, similar languages, culture and traditions, common history heritage, intensive migration and Ukrainian

\footnotetext{
2 The interview transcripts have been made available courtesy of sociologist Viktoriya Volodko, Ph.D. and research fellow at the Centre for Social Monitoring, the Ivan Franko National University of Lviv. She conducted these interviews in Warsaw in 2005.
} 
Diaspora comprise the factors favorable for a migrant's integration. In spite of these factors, the respondents consider migration as a merely temporary way of improving the economic conditions of their families in Ukraine and are not interested in integrating with the new society (cf. the situation with the Polish migrants into the USA). (Mach 1993: 179) Thus, these women do not have a good basis for any identity reconstruction. Their situation is a good example of the "between and betwixt" position. ${ }^{3}$ (Eriksen 1993: 73) They cannot stay in Ukraine due to difficult economic conditions, but neither can they stay in the host society for a long period of time. Some of the respondents have to come back to their families in Ukraine due to various family problems, others do not like their work and cannot get used to their new work conditions. Also, illegal work is source of their numerous problems (only one out of twelve respondents' works legally at the moment of interview). The emotional attachment and nostalgia for Ukraine is another important reason for only temporary staying in Poland. Female labour migrants do not consider their situation in Poland as stable. They first and foremost spoke of, first of all, the legal status, insurance, regular wages etc. In effect, the reconstruction of these temporary migrants' personal identities is impossible due to the luck of basic security (i.e. the absence of legal status, precarious labour position and divided families).

Any changes in a person's life (e.g. migration abroad) seriously influences the personal identity. Migrants' integration into the new society is done in the atmosphere of conflicts and misunderstandings after which the integration with, or even assimilation into a new community, follows, not always though. The first difficulty for many migrants is the language of the host society, one of the most important aspects of identity; a "tool" for identity creating and the "we - they" marker. Moreover, it is also a marker which draws symbolic and invisible but strong "boundary barriers" between people. Despite the fact that numerous respondents have certain knowledge of Polish language, the majority of them also experience difficulties in understanding and speaking, particularly at the beginning. Correspondingly, as their length of stay increases, their language skill improves. Thus language - one of the most important barriers for the identity reconstruction and integration into the host society - gets partly improved in the course of time.

3 T.H. Eriksen used this concept for describing the situation of persons whose ethnic identities and background are vague (the so called "ethnic anomalies"). E.g. "If your father is a Cree Indian and your mother is Francophone Canadian, or visa verse, what about yourself?" (Eriksen 1993: 62) I am using this concept for describing the specifics of the identification process of temporary labour migrants. 
Religion, and church specifically, is an integrative phenomenon for Ukrainian labour migrants. Not only is the Greek-Catholic church at Miodowa Street in Warsaw a spiritual religion unit; it is also a place where migrants can look for help, news and the job as well as meet friends and compatriots. Most of the respondents does not feel a considerable change in their religion identity after immigration to Poland because they are Greek Catholics and continue to visit the Greek-Catholic church in Warsaw. Church activities are a combination of the traditional religion identity support and, at the same time, help create new opportunities for migrants in the migrant identity-reconstruction space, among other migrants so as to feel more secure in the new conditions. Thus church favors supporting the "old" identity of labour migrants as well as the simultaneous re/construction of the "new" one.

Regarding the professional identity, a conflict between the perception of an old (in Ukraine) and a new professional position (in Poland) on the labour market is observed among the respondents. All the interviewed female labour migrants work in the domestic sector. They care for old people and children and perform domestic work. Women stress the low social status and relatively low wages in spite of good relations with their employers. It is a typical example of a "brain waste" because these women used to be teachers, accountants, nurses and doctors back in Ukraine. The luck of job satisfaction constitutes one of the important reasons why these women do not want to stay in Poland for a long time. In spite of their higher education, respondents are hardly able to find better work, first of all due to the structural obstacle of representing another nation-state. The luck of good knowledge of the Polish language and illegal or half-legal stay in the host society make it hardly possible to change their labour position, at least at the begging of their professional trajectories in Poland. This situation is a basis for the permanent professional identity conflict. The respondents are not happy to be cleaners or nannies but they cannot get any other work in Poland, and their families in Ukraine wait for the remittance. A lot of female migrants miss their previous employment and cannot "forget" belonging to another - better - professional group.

The reconstruction of family identity (first of all that of a mother and a wife, but also one of a daughter and a sister) is a big challenge for female labour migrants. Their decision for migration has been undertaken with an aim to provide welfare for family members, especially for children, but, at the same time, this decision becomes the foundation of the respondents' emotional difficulties. The guilt for being away as well as the very fact of being distant from families 
might cause depression or, vice versa, increase individualization of a woman who continues to send the remittance and talks on phone with family members simultaneously thinking about herself, her life and interests.

Also, staying abroad intensifies the perception of the national identity and homesickness. The common territory as "a basic feeling of belonging and a symbolic component of a group's identity" (Mach 1993: 175), one's own state, a common language, religion, customs and traditions (i.e. the indicators of national identity) are important integrative factors for Ukrainian labour migrants. Back at home, the above mentioned indicators had a non-central place in the structure of the Ukrainian migrants' personal identity. However, they moved from the periphery to the central part of the migrants' personal identity in Poland. Perceiving themselves as Ukrainian citizens became especially relevant after the so-called "Orange Revolution" (2004-2005). The revolutionary events strongly increased the female migrants' degree of national self-consciousness. When talking about the "Orange Revolution," the women have always highlighted the help and support of Polish citizens.

On the other hand, the regional identity of migrants is weak. Only in a few cases have I came across the identity construction grounded in the traditional opposition between the western and the eastern Ukraine.

In terms of belonging into the "we-them" model, the Polish natives are perceived by respondents as closer to "us" then to "them." The interviewed women are considered Poles rather than Russians, but Russians - are "felt" as "closer" to their regional sense of themselves than e.g. German natives.

\section{Conclusions}

This paper has demonstrated that the reconstruction of temporary labour migrants' identities is complicated and multidimensional. Actually, female labour migrants are not interested in the integration into the Polish society due to their perception of labour migration as a temporary activity aimed at money-making. Additionally, the precarious legal and labour status of female migrants constitutes an obstacle as regards the reconstruction of their personal identities. Consequently, these migrants are isolated in the host society. On one hand, they need to maintain their old identities, and, on the other hand, they have to integrate and reconstruct their identities abroad. Most of the female labour migrants, however, were dissatisfied with the level of life in Ukraine after they had returned home. Such a clash of two different types of the economic conditions produces a conflict 
of personal identities and values. Temporary labour migrants do not want to live in Ukraine, but they also cannot live in Poland as fully-fledged citizens.

The conflict and the integration represent two sides of one coin with reference to the identity reconstruction process. Conflicts and misunderstandings are always a part of the identity crisis and, at the same time, they are the initial elements of the said reconstruction. After the language barrier has disappeared, many cultural differences between people are still left and it takes a long time for them to vanish.

According to some researchers, temporary Ukrainian labour migrants are this part of population who actively adapts to the new ways of life and is better prepared for crises and difficulties. (Прибиткова 2003) Probably this is true, yet, even if so, nobody ask these people: "Do you want it?" "Do you like your situation?" or, at least "Are you satisfied with your new conditions?" Temporary labour migration is a big challenge for every person. It involves the continuous identity change and reconstruction in people who are all time in the "between and betwixt" position.

All in all, this research confirms that the "migrant or minority cultures are constantly recreated on the basic of the needs and experience of the group and it is interaction with the actual social environment." (Castels, Miller 1993: 34) This process is more complicated on the personal level and depends on many factors. $\mathrm{Be}$ it as it may, "identity is formed in a force field of integration, adaptation and conflict and because in both cases identity is a subjective and symbolic character." (Mach 1993: 179)

\section{WORKS CITED}

Castles, Stephen, J. Mark Miller. The Age of Migration: International Population Movements in the Modern World. London: Macmillan. 1993: 307.

Conditions of work: International labour migration. Geneva: ILO Publishers 1996.

Eriksen, Thomas Hylland. Ethnicity and Nationalism. Anthropological Perspectives. London: Pluto Press 1993: 224.

Korczyńska, Joanna. Sezonowe wyjazdy zarobkowe Polaków do Niemiec. Warszawa: Wydawnictwo Naukowe Scholar 2003: 198.

Mach, Zdzisław. Symbols, Conflict and Identity. Essays in Political Anthropology. Albany: SUNY Press 1993: 297.

Richmond, Anthony H. Immigration and Ethnic Conflict. London: Macmillan 1988: 226. 
Soanes, Catherine (ed.). English Oxford Dictionary. Oxford University Press 2002: 990. Давимука, Степан, Антоніна Колодій, Юрій Кужелюк, Володимир Подгорнов, Наталія Черниш. Львівщина на порозі XXI століття: Соціальний портрет - Львів: Ін-т регіональних досліджень НАН України. 2001: 351.

Зовнішня трудова міграція населення України: звіт. Київ: Укр. центр соц. реформ, Держ. ком. статистки України 2009: 119.

Паніна, Наталія. Українське суспільство 1994-2005: соичіологічний моніторинг. Київ: ТОВ “Видавництво Софія” 2005: 160.

Прибиткова, Ірина. „Трудові мігранти у соціальній ієрархії українського суспільства: статусні позиції, цінності, життєві стратегії, стиль і спосіб життя.” Сочіологія: теорія, методи, маркетинг 4, 2002: 156-167.

Прибиткова, Ірина. „Трудові мігранти у соціальній ієрархії українського суспільства: статусні позиції, цінності, життєві стратегії, стиль і спосіб життя." Сочіологія: теорія, методи, маркетинг 1, 2003: 109-124.

Фрідмен, Томас Лорен. “Лексус і Оливкове дерево. Зрозуміти глобалізацію.” Пер. з англ. Мар'яни Прокопович та Роман Скакуна. Незалежний Культурологічний Журнал “ї" 2002: 622.

\section{Summary}

This paper focuses on the reconstruction of some migrants' identities in the context of contemporary labour migration. The article is based on a study of temporary female labour migrants from western Ukraine in Poland and includes twelve semi-structured interviews with Ukrainian women who have an experience of work in Warsaw. The research of S. Castels and M.J. Miller as well as Polish scholar Z. Mach provide the theoretical and methodological framework of this paper. The essay discusses both the migration context and the linguistic, religion, professional, family, national and regional identities of the women in question. It demonstrates that the reconstruction of the temporary labour migrant identity is a complicated and multidimensional process (involving conflict and adaptation in the same time). In spite of many favourable factors female labour migrants are interested neither in the reconstruction of their personal identities, not the integration into the Polish society due to the perception of their migration as only a temporary activity aimed at money-making. Additionally, the precarious legal and labour status of respondents creates an obstacle for the smooth advancement of these processes.

Keywords: Ukraine, Poland, labour migration, identity reconstruction 


\title{
MIGRACJA I REKONSTRUKCJA TOŻSAMOŚCI PRACUJĄCYCH CZASOWO MIGRANTÓW Z UKRAINY W POLSCE
}

\begin{abstract}
Streszczenie
Artykuł oparto na badaniu przemian tożsamości pracujących czasowo migrantów z Ukrainy w Polsce. W sposób szczególny refleksja poświęcona jest kobietom - migrantkom z zachodniej Ukrainy. W pracy wykorzystano 12 wywiadów pracownic z terenu Warszawy. Akcent położono na kwestie tożsamości językowej, religijnej, zawodowej, rodzinnej, narodowej i regionalnej.
\end{abstract}

Słowa kluczowe: Ukraina, Polska, pracująca migracja, rekonstruowanie tożsamości 